\title{
Isolating Mercury-resistant Bacteria from Lake Maharloo
}

\author{
Maasoomeh Aram ${ }^{1}$, Asghar Sharifi ${ }^{2}$, Farsheed Kafeelzadeh ${ }^{1}$, Mohsen Naghmachi ${ }^{2} \&$ Esmaeil Yasari $^{3}$ \\ ${ }^{1}$ Islamic Azad University, Jahrom Branch, Iran \\ ${ }^{2}$ Department of Microbiology, Medical University of Yasuj, Yasuj, Iran \\ ${ }^{3}$ Department of Agriculture, Payame Noor University, Iran \\ Correspondence: Asghar Sharifi, Department of Microbiology, Medical University of Yasuj, Yasuj, Iran. E-mail: \\ asgharsharifi@yahoo.com
}

Received: November 23, 2011

Accepted: December 8, 2011 Online Published: June 13, 2012

doi:10.5539/ijb.v4n3p63

URL: http://dx.doi.org/10.5539/ijb.v4n3p63

\begin{abstract}
Mercury is one of the most poisonous heavy metals, and because it is heavily used in industry, agriculture, dentistry, gold mining, etc., it pollutes the environment and the organisms living in it are threatened even by small amounts of mercury. Low concentrations of mercury cause chronic and acute poisoning and disorders in the senses of sight, hearing, and the nervous system; and; by passing the blood-brain barrier and the placenta, bring about brain damage, lack of mental development, blindness, and speech impairment of the fetus. The bacteria present in areas polluted by mercury are able to remove it from the environment through a reduction process. The salt lake of Maharloo is situated $23 \mathrm{~km}$ southeast of the city of Shiraz. All domestic, manufacturing, industrial, hospital, and agricultural wastewaters of Shiraz enter the lake via the Khoshk, Fassa Bridge and the Salameeyeh rivers and pollute it. Among the pollutants of the lake are heavy metals, especially mercury. The goal of this research was to isolate and identify mercury-resistant halo-tolerants from the water and the sediments present in the lake, and to investigate their capability in eliminating the mercury in the lake. After sampling water and sediments from four stations in the lake in all four seasons of the years, the mercury-resistant halophilic bacteria were isolated through enriching them in the L. B. Broth medium and culturing them in L. B. Agar containing salt and mercury. By measuring the mercury left in the environment using an atom absorption apparatus, the capability of the isolated bacteria that were most resistant to mercury in removing mercury was calculated and their growth synthetic studied. Mercury-resistant bacteria have a deciding role in the absorption and removal of this element from the environment. Strains of mercury-resistant halotolerant bacteria include those of Escherichia coli, Vibrio spp., Klebsiella spp., Citrobacter spp., etc.
\end{abstract}

Keywords: mercury, Maharloo Lake, mercury-resistant halotolerants

\section{Introduction}

Water is a vital liquid having a very important role in the conservation and survival of living creatures; and it is also required in most chemical reactions. Nonetheless, a substantial part of water used at homes, in industry, and in agriculture is turned into effluents which can result in the pollution of surface and underground water and also of the environment (Rezaee, 2009). On the other hand, the sudden growth in industry, the population explosion, and the revolution in agriculture greatly influenced the physical environment of human beings. Moreover, drugs, antibiotics, radioactive materials, and industrial waste contain mutagenic, carcinogenic, and teratogenic heavy metals. Many of the heavy metals have harmful effects on living things and on life (Afrasayab et al., 2007). One of the most important undesirable consequences of dumping industrial wastewater in surface waters is the death of aquatic creatures, especially fish, the disintegration of the bodies of which also will result in further pollution of the area involved (Mirzaee, 2007). Nowadays, many countries are faced with numerous problems in treating effluents which can cause irreparable damages to the environment and to the health of human beings and other living organisms. Due to the importance of this issue, rectifying the pollution brought about by effluents through the use of modern technologies has been one of the important questions attracting interest in recent years; and so far many successes have been achieved regarding the application of newly developed methods which can have a very significant role in ensuring the health of living creatures (Afrasayab et al., 2007).

Industrial effluents are effluents the chemical constitutions of which depend on the type of the industrial activities producing the effluents. Entrance of industrial effluents into seas, rivers, and lakes pollutes the waters; 
and will hence bring about the death of aquatic creatures. Factories and their products cause the chemical pollution of industrial effluents. Arsenic, mercury, and lead are among the most important elements present in the effluents of factories producing paper, plastics, and chemicals for controlling plant pests; and these elements cause the pollution of the environment and of the flowing surface waters (Banaee, 1994). Mercury is one of the major, and very poisonous, polluters of the environment: it is a mutagen, inhibits growth, possesses poisonous effects, and is the reason for many of the important human diseases and syndromes. The effects of mercury on the performance of the ecosystems are economically and hygienically significant. Mercury causes chronic and acute poisoning (Afrasayab et al., 2007).

Organic mercury compounds, especially alkyl derivatives such as ethyl mercury halogens, are very poisonous, bring about severe visual disorders, usually cause the destruction of some of the surface and dorsal nerves of the spinal column, and also affect brain neurons. Alkyl mercury halogens cause skin irritation and can bring about severe skin diseases. Dimethyl mercury is highly poisonous and causes severe damages (Rezaee, 2009). Small amounts of this mercury compound can have harmful effects for months. Besides human beings, plants, and animals, mercury can affect the growth of bacteria. Although many bacteria are able to grow in environments rich in mercury (Afrasayab et al., 2007) many aquatic plants and animals can absorb mercury and the organisms on the lower echelons of the food chain (such as the planktons) can trap mercury in their bodies. When planktons are eaten by higher herbivores or carnivores in the food chain, mercury is transferred to their bodies and finally ends up in fish, which are consumed by people (Mirzaee, 2007).

According to recent calculations, from 4800 to 8300 tons of mercury enters the environment every year. It costs thousands of dollars to remove one pound of mercury from the environment by using common present day technologies. Therefore, alternative and practical techniques of removing mercury from the environment must be developed (Kiefer, 2000). Chemical methods of removing heavy metals and mercury from water and effluents, besides the high costs involved which deters industrialists from employing such techniques, cause the problem of the sludge produced from the chemical sediments and sludge itself is waste matter which causes problems and which is incompatible with the environment (Fooladi Fard, 2004). Therefore, the biological method of removing heavy metals from the environment attracts attention since it is both economically viable and also compatible with the environment. This process, in which microorganisms are employed to reduce and eliminate metallic (mercury) pollutants, is called bioremediation. Among the most important bacteria which can be used for this purpose are the bacilli, the pseudomonas, the vibrios and the family enterobacteriaceae (Banaee, 1994).

The entrance of industrial effluents into the surface waters provides a favorable environment for the anaerobic bacteria in the water which do not need oxygen to grow. This will create a disagreeable odor in the water, and will also result in the production of poisonous and combustible materials; hence, the environment will become unsuitable for aquatic life forms. Mechanisms of metal resistance in many bacterial groups have been discovered. Bacteria have extensive capabilities at cellular and molecular levels to overcome stresses present in the external environment (Afrasayab et al., 2007). The biological methods, which are used to eliminate heavy metals present in effluents and polluted waters, are both economically viable and also compatible with the environment. These methods employ living organisms (bacteria, yeasts, algae, fungi, plants, etc.), among which bacteria enjoy greater significance compared to other organisms, since they possess systems resistant to heavy metals and also contain degrading enzymes (Afrasayab et al., 2007).

Lake Maharloo is situates $23 \mathrm{~km}$ southeast of the city of Shiraz, it has salty water with average salt content of 220 grams per liter, and is polluted by various kinds of pollutants entering it via the intermittent streams of Khoshk, Fassa bridge, Nazrabad, Sarvestan, and Salameeyeh (Rezaeeyan, 2004). In the areas around the rivers entering Lake Maharloo, especially the area surrounding the Khoshk river, many industrial, urban, and agricultural activities take place, for example in the Nargess-e-Shiraz factory, the Zamzam beverages factory, the Shiraz alcohol production factory, the Pas Chemicals factory, hospitals, service stations, restaurants, etc. In the effluents of each of which there are different heavy metals which finally empty into Lake Maharloo (Rezaeeyan, 2004). The purposes of conducting this research were: (1) to measure the mercury content of the water and sediments of Lake Maharloo, (2) to isolate and identify the mercury-resistant bacteria of this lake (because mercury is the most poisonous heavy metal), (3) to investigate the growth synthetic of these bacteria in order to employ them for the treatment of the effluents of factories and of pollutants, and (4) to study the hypothesis that there is a relationship between a rise in the pollution of the environment by mercury and an increase in the probability of isolating mercury -resistant bacteria. Since the lake is salty, the bacteria in it are mercury-resistant halotolerants. 


\section{Materials and Methods}

The areas studied were the entrances of the Khoshk, the Fassa bridge, and the Salameeyeh rivers, plus the middle part of the lake - i. e., four stations were selected (refer to the figure). The entrances of the three rivers into the lake, which were the most polluted, were selected for isolating mercury-resistant halobacteria, and the middle part of the lake, which was less polluted, was chosen as the control station. At the time of sampling, the geographical positions of the stations were determined by using the GPS.

\subsection{Preparation of the Samples for Measuring the Mercury Content}

\subsubsection{Water Samples}

The samples were filtered, using (Watchman's filter paper $42 \mathrm{~mm}$ ) to remove the impurities. All filtered samples were dissolved in a 3:1 mixture of nitric and hydrochloric acids.

\subsubsection{Deposit Samples}

The samples were first completely uniformed, then were placed in Petri dishes and weighed by scales, after that were put in the oven (set at $103{ }^{\circ} \mathrm{C}$ ) to be dried, and, finally, were weighted again to determine their moisture percentage. Then, from each dried sample, one gram was taken and $10 \mathrm{ml}$ of a 3:1 mixture of nitric and hydrochloric acids was added to it. These samples were heated and then filtered, using (Wattman's filter paper 42 $\mathrm{mm}$ ), to remove the impurities. After that, distilled water was added to increase the volume of each of the samples to $100 \mathrm{ml}(5)$. The mercury content of each water or sediment sample was measured using the cold vapor method and employing atom absorption apparatus

\subsection{Counting Bacteria}

The number of bacteria was determined by employing the Viable Plate Count method. First, $10^{-1}$ to $10^{-9}$ dilutions of each water or sediment sample were prepared. A pipet was used to take $0.1 \mathrm{ml}$ aliquots of each dilution to be put in two L. B. Agar media (one containing the metal mercury and the other without it), and the media were cultured using the surface plate method. The plates were kept in the hothouse at $30{ }^{\circ} \mathrm{C}$ for 48 hours. After the appearance of the colonies, the plates containing visible and countable colonies were selected and the colonies were counted. The numbers obtained were multiplied by the volume (the $0.1 \mathrm{ml}$ aliquots taken) and by the dilution (with positive powers) to determine the number of bacteria in the control environment and in the environment containing the metal mercury in CFU/gr, CFU/ml (Mirzaee, 2007).

In this research, the Luria Bertani broth medium (made by the German company Merck) was used for enriching the mercury - resistant bacteria. Since the L. B. Agar medium is a general medium and most bacteria can grow in it, $\mathrm{NaCl}$ was added to it at the concentration of $2 \%$ at preparation time, the medium was then autoclaved, and, finally, $10 \mathrm{mg}$ per liter concentration of bivalent mercuric chloride, or $\mathrm{HgCl}_{2}$, which had been sterilized using a 0.45- micron filter, was added so that the medium turned into a selective one. Next, the colonies which had formed were used to prepare pure cultures. The $\mathrm{pH}$ in all media used was set in the 7 to 8 range. Finally, the purified bacteria were identified according to the diagnostic methods described in Bergy's book, by using Gram stain and by conducting biochemical tests (Mirzaee, 2007).

\subsection{The Growth Synthetic of the Bacteria}

In order to determine the rate of growth of the isolated mercury-resistant bacteria in the presence of mercury, the resistant and the susceptible bacteria were separated in each season and their growth synthetic in the presence of mercury was studied so as to isolate the most resistant bacteria in each season. First, 24-hour cultures in L. B. Broth were prepared from all mercury-resistant bacteria isolated in each season. After the bacteria had grown, for each genus, $100 \mathrm{ml}$ L.B.broth media in Erlenmeyer flasks were prepared at the concentration equivalent to 0.5 McFarland. To the first medium, mercury chloride $(5 \mathrm{mg} / \mathrm{l})$ was added at the beginning. The same amount of mercury chloride $(5 \mathrm{mg} / \mathrm{l})$ was added to the second medium in the middle of the logarithmic growth phase (that is, 240 to 320 minutes later). The third medium, which did not contain the metal, was selected as the control. Next, each of these three Erlenmeyer media was inoculated with one $\mathrm{ml}$ of the bacterial suspension. One Erlenmeyer flask containing the L. B. Broth medium was also used for calibrating (setting at zero) the spectrophotometer. Immediately after inoculation with the bacterial suspension, light absorption in each of the media was read at the wavelength of $540 \mathrm{~nm}$. Next, the media were shaken at 30 degrees centigrade in an autoclave equipped with a shaker for 12 hours at $150 \mathrm{rpm}$, and then their light absorption in the second stage was read for half an hour, and from then on it was read for one hour. This process was repeated for 12 consecutive hours and, finally, the growth of the bacteria in the presence of mercury was obtained (Mirzaee, 2007). 


\subsection{Statistical Analysis}

The statistical analyses concerning the number of bacteria were performed using analysis of the variance (ANOVA), and the Duncan test was conducted employing the SPSS software.

\section{Results}

\subsection{The Mercury Content of the Samples}

The highest mercury content in the water samples $(29.951 \mu \mathrm{g} / \mathrm{l})$ and in the deposit samples $(31.251 \mu \mathrm{g} / \mathrm{l})$ were observed at the Fassa bridge station, and the lowest mercury content in the water samples $(15.243 \mu \mathrm{g} / \mathrm{l})$ and in the deposit samples $(18.067 \mu \mathrm{g} / \mathrm{l})$ at the station that was situated in the middle part of the lake.

\subsection{Bacteria Count}

The largest numbers of mercury resistant bacteria were found at the Khoshk and Pol-e-Fassa stations $\left(8.37 \times 10^{4}\right.$, and $2.8 \times 10^{3}$, respectively), and the smallest at the station in the middle part of the lake $\left(4 \times 10^{2}\right)$. The Khoshk and the Fassa Bridge were not significantly different from each other in this respect. The differences among other stations concerning the number of mercury resistant bacteria were significant at the $5 \%$ level.

The averages of the number of bacteria in the medium containing mercury (the mercury resistant bacteria) were much smaller than those of the bacteria in the control medium (the total number of aerobic bacteria that could be cultured), and the differences between these averages were significant at the $5 \%$ level (Figure 3). Isolation and identification of mercury resistant bacteria revealed that the percentage frequency of gram negative bacteria identified was higher than that of the gram positive bacteria identified and that these frequencies were significantly different at the $5 \%$ level: $65 \%$ of isolated mercury- resistant bacteria were gram negative and $35 \%$ gram positive. The largest frequency percentages of the identified bacteria at the different stations in the different seasons were those of Vibrio $S p$ (with 75\%), and the smallest those of V.parahemolyticus (with $6.25 \%$ ) and Citrobacter (with 12.5\%)

\subsection{Growth Synthetic}

The growth synthetic curve of bacteria more resistant to mercury in the presence of $5 \mathrm{mg} / \mathrm{l}$ of mercury chloride almost followed the standard growth curve. The presence of mercury in the culture medium of Pseudomonas influenced the length of the lag phase and the logarithmic growth of the bacteria, and caused an increase in the length of the lag phase and in the logarithmic growth of the bacteria. The maximum growth rate in the presence of bacteria was exhibited by $V$. alginolyticus isolated in summer (Figures 1 and 2).

The Figures of the growth of the resistant bacteria isolated in spring and winter indicate the longest lag phase (three to four hours), with the greatest length of the lag phase (four hours) belonging to Staph bacteria isolated in winter. When mercury was added to the culture medium of these bacteria, no great changes were observed in their $\mathrm{A}$ and $\mathrm{C}$ line, but their $\mathrm{B}$ line in the logarithmic phase, and then in the static phase, showed a great reduction in growth compared to the $\mathrm{A}$ and $\mathrm{C}$ line, and their OD decreased by more than half as compared with line $\mathrm{A}$ (Figures 5 and 6). This situation was also observed in Citrobacter isolated in spring: adding mercury in the middle stage of the process caused a marked decrease in the growth of the bacteria, so that the B growth curve was completely separated from those of A and C (Figure 7). The growth curve of Vibrio is almost normal in the fall (Figure 4). The growth curve of E. coli shows that mercury added in the middle stage of the process caused a great reduction in the $\mathrm{B}$ curve as compared to those of $\mathrm{A}$ and $\mathrm{C}$ (Figure 8). This reduction took place in the logarithmic stage, so that the OD of curve B is considerably reduced as compared with that of line A (Figure 8). It can be said that the most normal and suitable growth curve under all conditions in the presence of mercury is that of the Proteus bacteria, especially the Proteus bacteria isolated in the fall (Figures 3 and 6). 


\section{V.alginolyticus}

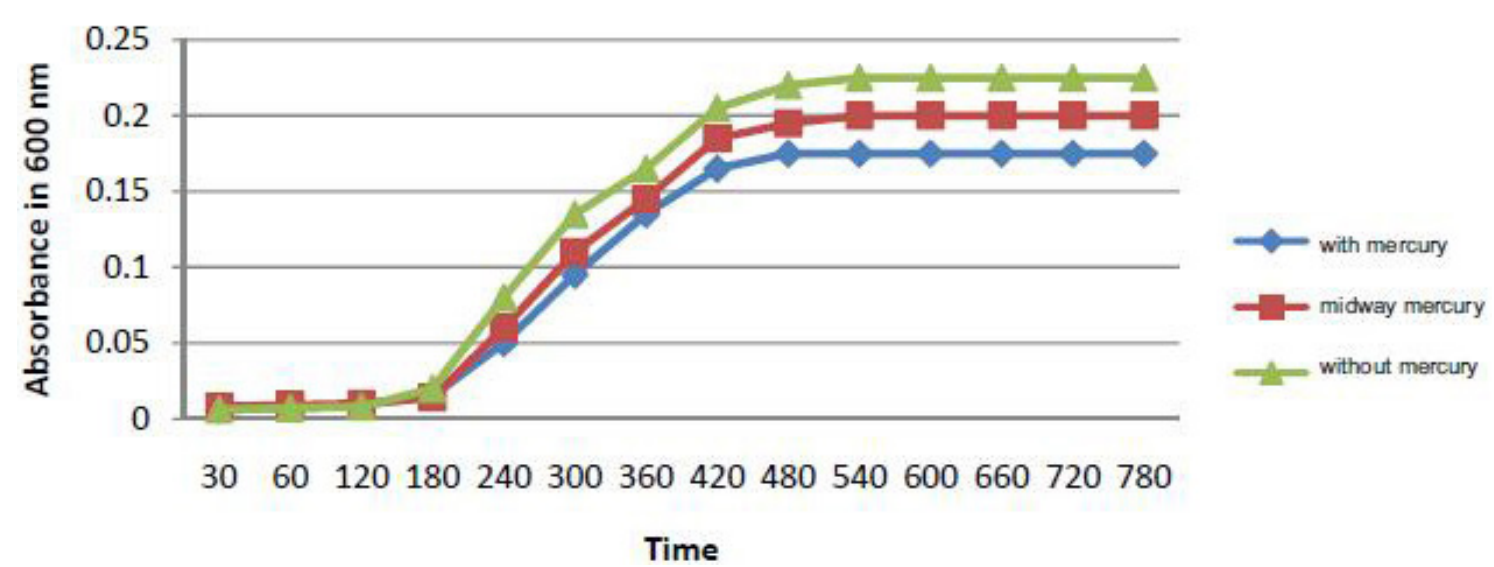

Figure 1. The growth synthetic of the bacteria V. alginolyticus in the summer of 2009

\section{Pseudomonas}

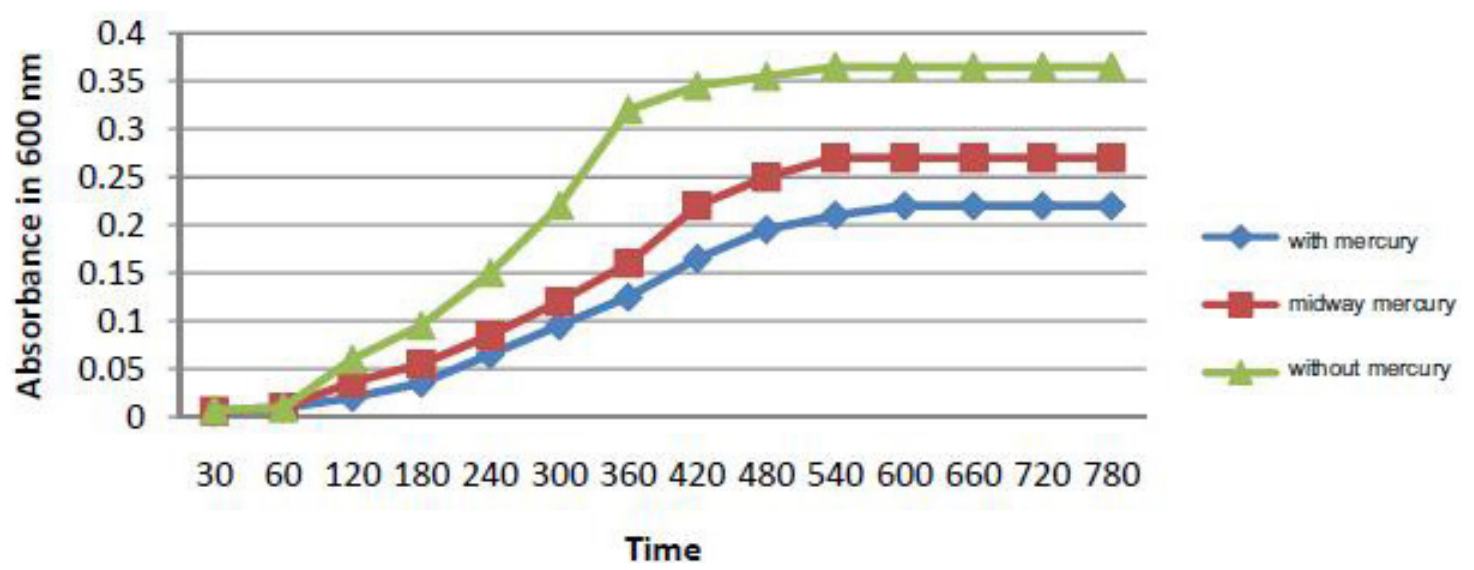

Figure 2. The growth synthetic of the bacteria Pseudomonas in the summer of 2009

\section{Proteus}

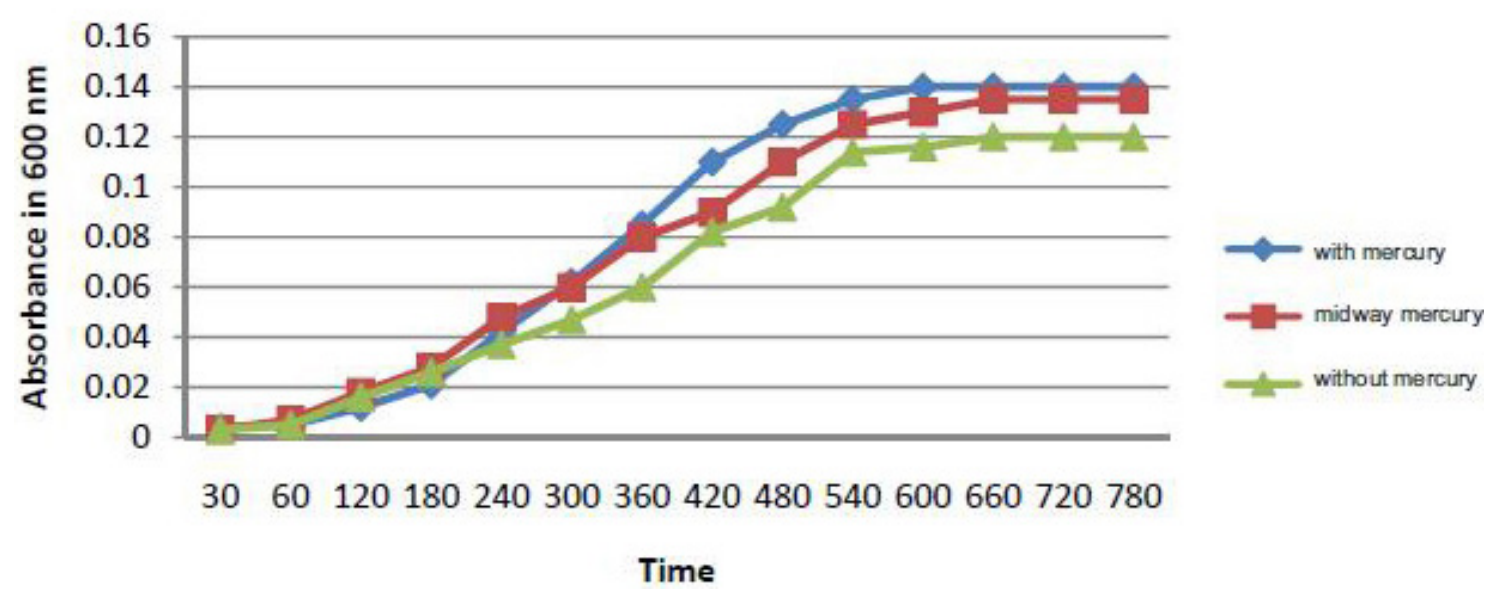

Figure 3. The growth synthetic of the bacteria Proteus sp in the fall of 2009 


\section{Vibrio}
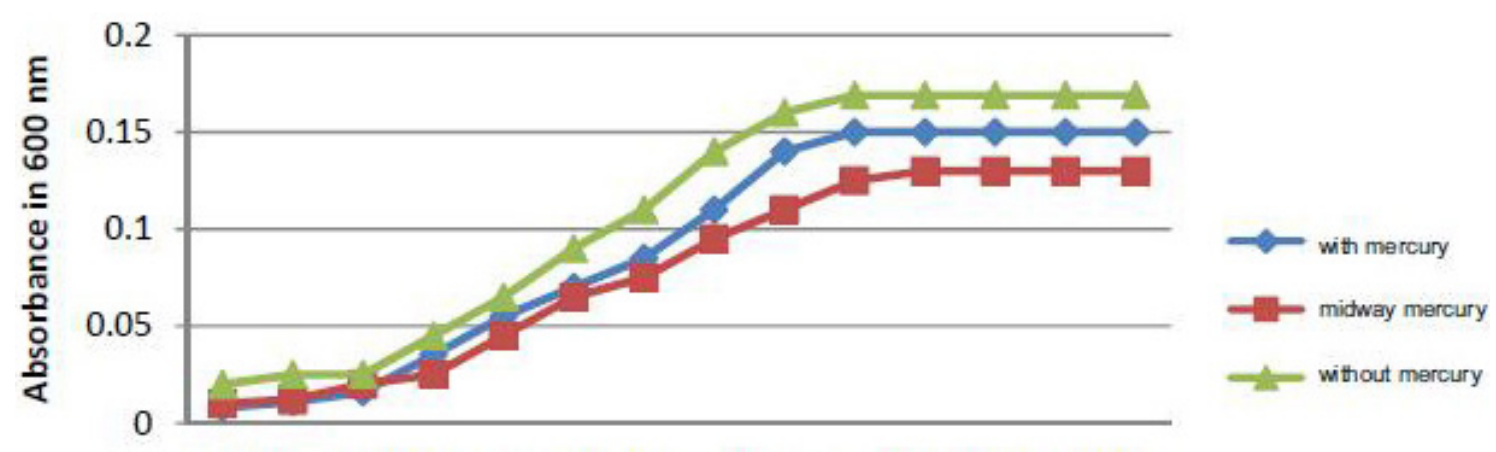

$30 \quad 60120180240300360420480540600660720780$

\section{Time}

Figure 4. The growth synthetic of the bacteria Vibrio sp in the fall of 2009

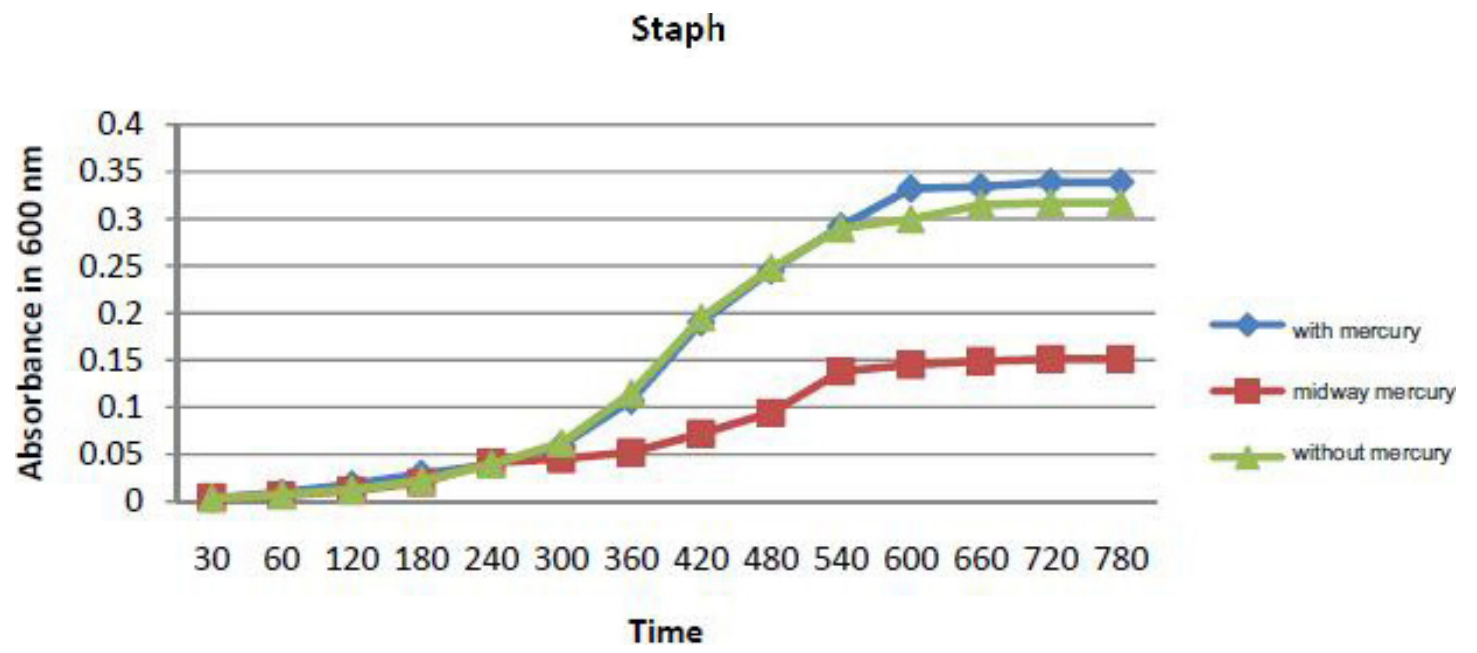

Figure 5. The growth synthetic of the bacteria Staph sp in the winter of 2009

\section{Proteus}

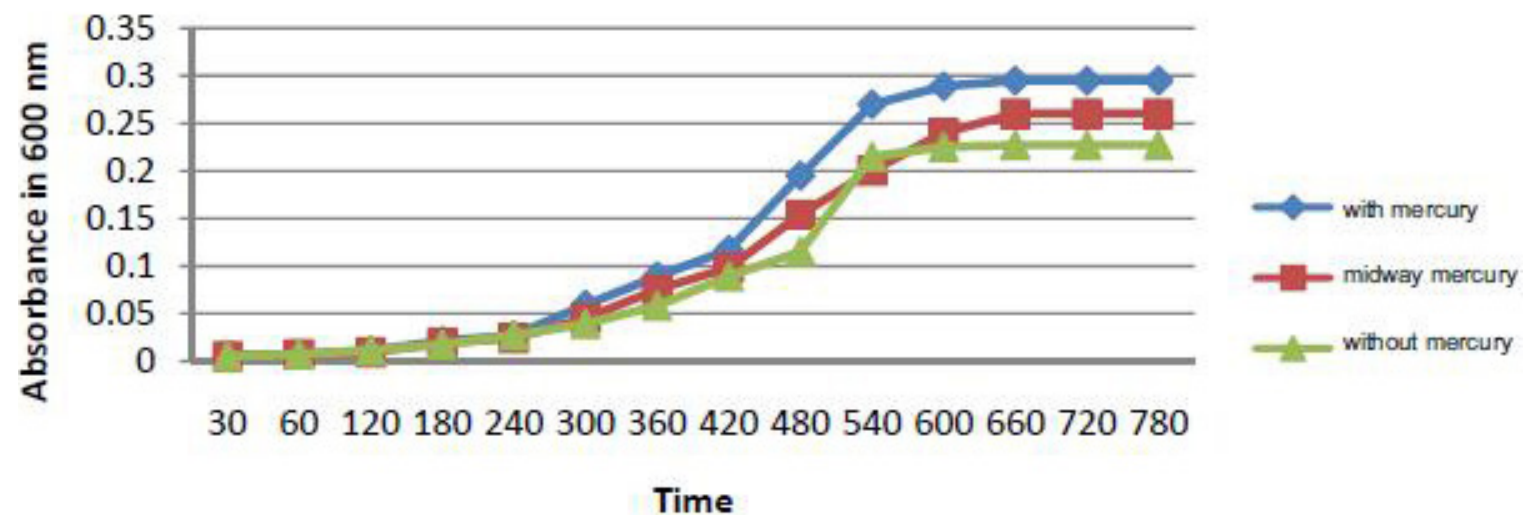

Figure 6. The growth synthetic of the bacteria Proteus sp in the winter of 2009 


\section{Citrobacter}
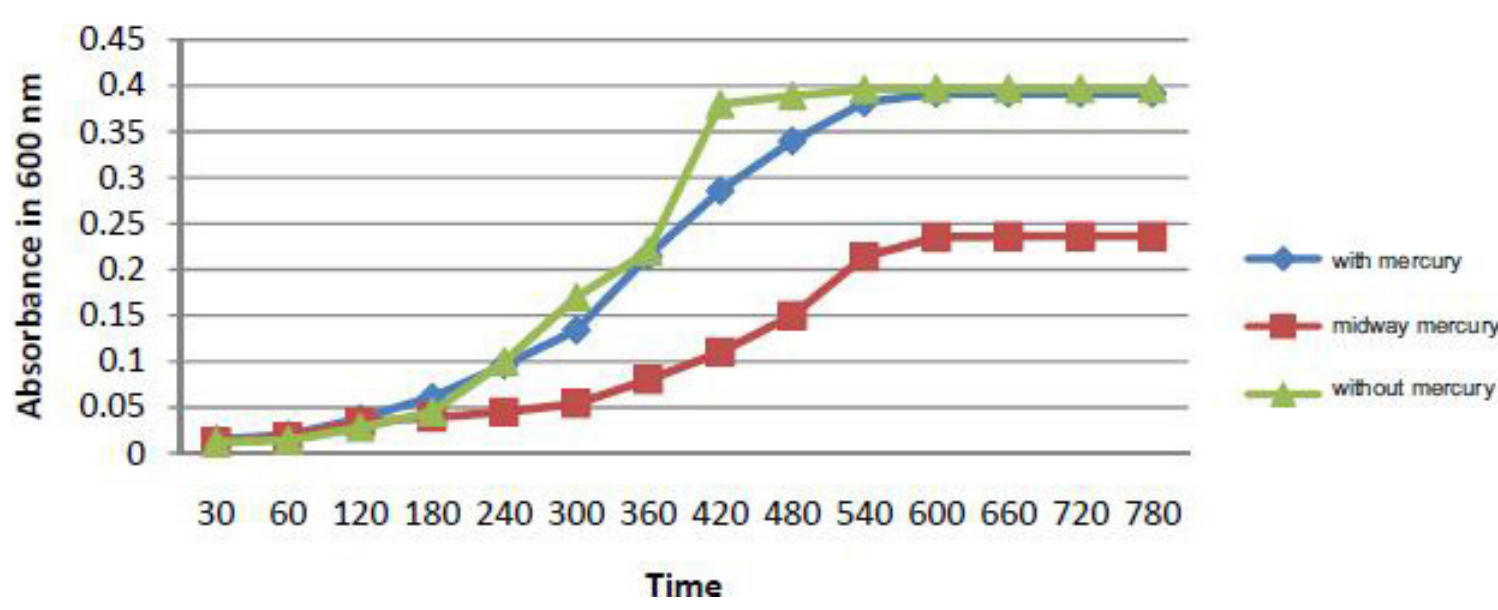

Figure 7. The growth synthetic of the bacteria Citrobacter sp in the spring of 2010

\section{E.coli}

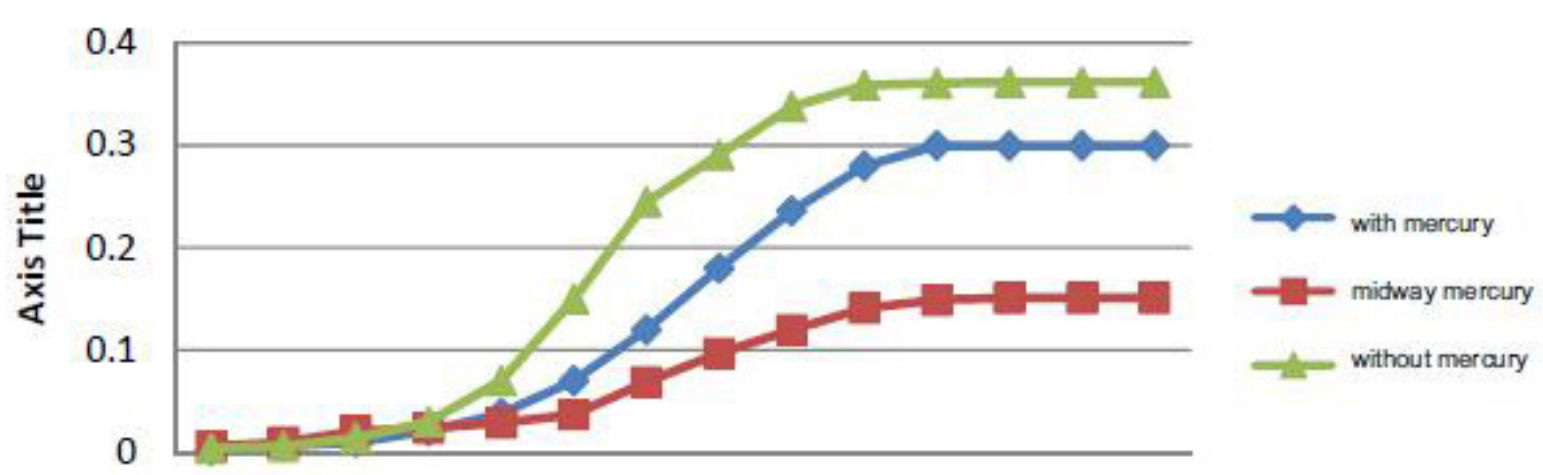

3060120180240300360420480540600660720780

Time

Figure 8 . The growth synthetic of the bacteria E. coli in the spring of 2010

\section{Discussion}

In this study, the highest concentration of mercury was found in the samples taken from the Fassa Bridge and Khoshk stations, and the lowest pollution was observed at the station selected in the middle part of the lake. Results of bacteria count in the control culture medium and in the medium containing mercury indicate that the number of bacteria in the control medium is larger than that in the medium containing mercury, because the presence of mercury in the culture medium stops the growth of many bacteria and kills a lot of them. In this research, the greatest number of mercury- resistant bacteria was detected in the spring and the smallest in the summer and in the fall. The temperature of the water in Lake Maharloo in spring varied from 16 to 18 degrees centigrade. Moreover, the water of the lake is saltier in summer than in spring. Therefore, the conditions prevailing in spring are optimum for the growth of bacteria in Lake Maharloo. In the research conducted by Mahler et al. in 1986, and by Barkay in 1987, the number of bacteria in the media containing mercury was much smaller than that in the control (without mercury) media (Barkay, 1987; Mahler et al., 1986).

In this research, as was expected, the greatest number of mercury-resistant bacteria were found at the stations of Khoshk and Pol-e-Fassa (which also had the highest level of mercury pollution), while the smallest number of mercury- resistant bacteria was detected at the station selected in the middle part of the lake (which had the lowest mercury concentration). 
Osbon et al. (1993) reported the number of mercury- resistant bacteria in the deposits of the four stations studied to be in the range of $9.1 \times 10^{3}$ to $6 \times 10^{6} \mathrm{CFU}$. They showed that the number of mercury- resistant bacteria was small at stations with a lower level of pollution.

In our study, the mercury-resistant bacteria were isolated by using the initial enriching method in the presence of $5 \mathrm{mg} / 1$ of mercury chloride and $2 \% \mathrm{NaCl}$, followed by the method of direct culture in solid medium. The bacteria isolated by employing the enrichment method showed better growth and more resistance in later stages in the presence of mercury, and possessed greater capability in removing mercury and in tolerating salt.

Wagner Dobler et al. (2000) used the direct culture method to isolate mercury- resistant bacteria from the effluents of factories producing alkaline chlorine, and isolated bacteria that possessed relatively low resistance to mercury.

In our research, the bacteria Pseudomonas, Bacillus, E. coli, and Vibrio Klebsiella were identified as mercury-resistant halotolerants. Essa et al. (2002) reported the bacteria Klebsiella, Staph, Serratia, Pseudomonas, E. coli and Bacillus as mercury- resistant bacteria in the Kor River. Pahan et al., (1990) reported mercury resistance in the genera Pseudomonas, Bacillus, E.coil, and Klebsiella.

In this research, different gram positive and gram negative mercury- resistant bacteria were identified. The frequency percentages of gram negative bacteria were higher than those of gram positive bacteria. Under unfavorable conditions, gram negative bacteria are able to intraspecifically and interspecifically pass to each other genes resistant to mercury through the process of conjugation. Besides this stage of the interaction of bacteria and mercury in the environment, there is the passage of this metal through the cell wall. Since gram negative bacteria have an external membrane (which stops the passage of poisonous materials into the cytoplasm), they are less affected by mercury than gram positive bacteria. Therefore, they are more likely to be isolated from the environment. In our study, bacteria such as E.coli, Vibrio, and Staph, which were isolated in spring and winter in the presence of mercury, needed more time to adapt themselves to new environmental conditions. During the adaptation period, bacteria grow very little. Therefore, the length of the lag phase will naturally increase due to the presence of poisonous materials (such as mercury) in the culture media.

Hansen et al. (1984) in their research on a number of mercury resistant bacteria in which they studied the growth of these bacteria in the presence of mercury, found that the presence of mercury increases the length of the lag phase.

Proteus $s p$ grows well in the presence of mercury since these bacteria have flagella all along their bodies and possess mer operon genes. Since these bacteria were isolated at the Fassa bridge, Salameeyeh, and Khoshk stations, which have the highest level of mercury pollution, it seems that the constant presence of mercury in the environment and the use of the enrichment method have adapted them to the stressful conditions resulting from the presence of mercury, and have turned them into resistant bacteria.

\section{Conclusions}

It was conclueded that Lake Maharloo is polluted by heavy metals, including mercury, entering it via rivers that empty into the lake. This is a threat to the ecosystem of the lake which harbors various and rare plant and animal species.

Results obtained from this research also indicate that there is a direct relationship between the increase in the concentration of mercury in the environment and the increase in the number of mercury resistant bacteria in these areas. The highest level of resistance to mercury was observed in the bacteria isolated from the Fassa Bridge and Kiosk stations; therefore, selection of polluted areas for sampling results in isolation of more resistant bacteria.

The bacteria isolated from the polluted areas possess a good potential in removing mercury from the environment. By providing the suitable conditions and substrates for the growth of these bacteria for the purpose of biological treatment of the effluents (filters and biological reactors), it will be possible to use these bacteria in the detoxification and elimination of the effluents polluting the environment in Lake Maharloo or in the other polluted areas of the country.

Vibrio was isolated from the studied stations in almost all seasons. Therefore, we can say that these bacteria are native to Lake Maharloo (the water of the lake is salty and these bacteria are halophiles), and that they have acquired the mercury resistant genes from resistant bacteria through plasmid transfer or from mer operon containing transposons. The genes the expression of which causes the bacteria to become resistant to mercury are mainly located on plasmids or transposons (Barkay, 1987; Barkay et al., 1989). 


\section{References}

Afrasayab, S. H., Yasmin, A., \& Hasnain, S. H. (2007). Characterization of some Indigenous mercury Resistant Bacteria from polluted Environment. Journal of Biological Science, 5(7), 792-797.

Banaee. (1994). Study of the pollution of the River Kor by Heavy Metals, the General Office of Environmental Protection of the Province of Fars. Publication Environmental Protection. p 123.

Barkay, T. (1987). Adaptation of aquatic microbial communities to Hg (II) stress. Appl Environ Microbiol, 53, 2725-2732.

Barkay, T., Liebert, C., \& Gillman, M. (1989). Environmental significance of potential for mer (Tn 21) mediated reduction of $\mathrm{Hg}(\mathrm{II})$ to $\mathrm{Hg}(0)$ in natural waters. Appl Environ Microbiol, 55, 1196-1202.

Essa, A. M. M., Macaskie, L. E., \& Brown, N. L. (2002). Mechanisms of mercury Biochem. Socie. Transc, 30, 672-674.

Fooladi Fard, R., Kamani, H., \& Khaefee, M. (2004). Elimination of Heavy Metals Using the Biological Absorption Method from Aquatic Solutions , the Ninth National Iranian Congress of Chemical Engineering, the University of Sciences and Industry. p. 335.

Hansen, C. L., Zwolinski, M. G., Martila, D., \& Williams, J. W. (1984). Bacterial removal of mercury from sewage. Biotechnology Bio Engineer, 26, 1330-1333.

Kiefer, N. (2000). Mechanisms of microbial metal resistance. Appl. Environ. Microbiol., 58, 1223-1226.

Mahler, I., Levinsol, H. S., Wang, Y., \& Halvorson, H. O. (1986). Cadmium and mercury resistance Bacillus strains from a salt marsh and from Boston harbor. Appl. Environ. Microbiol., 52, 1293-1298.

Mirzaee, N. (2007). Isolation of Micro-organisms removing Mercury from the Kor River, M. Sc. Thesis, Islamic Azad university of Jahrom. p. 210.

Osbon, A, M., Bruce, K. D., Strike, P., \& Ritchie. D. A. (1993). Polymerase chain reaction fragment length polymorphism analysis shows divergence among determinants from gram negative soil bacteria in distinguishable by DND-DNA hybridization. Appl. Environ. Microbiol., 59, 4024-4030.

Pahan, K., Ray, S., Gachui, R., Chaudhuri, J., \& Mandal, A. (1990). Ecological and biochemical studies on mercury resistance bacteria. Indian J. Environ. Health, 32, 250-261.

Rezaee, A. (2009). Elimination of Mercury from the Effluents of the Shiraz Petrochemical Complex Using Biotechnological techniques, a Research Project, The Tarbiyat-e-Modarress University, the National Petrochemical Industries Company. p. 220.

Rezaeeyan, S. (2004). Study of the microbial and chemical pollution of Lake Maharloo, M. Sc. thesis, the Islamic Azad University of Jahrom. p. 189.

Wagner Dobler, I., Lunsdorf, H., Lubbenhausen, T., Von Canstein, H., \& Li, Y. (2000). Structure and species composition of mercury reducing biofilms. Appl. Environ. Microbiol., 66, 4559-4563. http://dx.doi.org/10.1128/AEM.66.10.4559-4563.2000 